\title{
STUDIES OF THE BLOOD-CEREBROSPINAL FLUID BARRIER TO CORTISOL IN THE DOG *
}

\author{
By NICHOLAS P. CHRISTY AND ROBERT A. FISHMAN $\dagger$ \\ (From the Departments of Medicine and Neurology, Columbia University College of Physi- \\ cians and Surgeons, and the New York State Psychiatric Institute, \\ New York, N. Y.)
}

(Submitted for publication May 17, 1961; accepted July 27, 1961)

This study was undertaken to investigate the entry of administered cortisol and one of its metabolic products into the cerebrospinal fluid (CSF) of dogs under a variety of conditions. Cortisol, ${ }^{1}$ one of the principal circulating adrenal cortical steroids of man $(1,2)$ enters the CSF $(3-5)$, but little is known about the rate at which it passes into the CSF or what factors regulate its passage. Although the relationship of CSF to the extracellular fluid of the brain is complex, it is generally accepted that the two compartments are in equilibrium, and that the blood-CSF and blood-brain barriers do not differ qualitatively in their respective permeability characteristics $(6,7)$. The data of this study on the entry of cortisol into CSF can therefore be considered relevant to the problem of penetration of cortisol into the brain. This is of some clinical importance with respect to the known effects of cortisol upon brain metabolism; e.g., upon seizure threshold and emotional state (8).

There are abundant data which show that the rate of entry of many substances into the CSF is determined by certain of their physical and chemical properties. These properties are solubility in lipid solvents, binding to plasma protein, molecular size, and in the case of salts of weak acids and bases, $\mathrm{pK}(6,7,9)$. Since neutral steroids have no $\mathrm{pK}$, and molecular size is not an important determinant of rate of entry into the CSF except with substances of very high molecular weight $(6,7)$, only lipid solubility and binding to plasma

* Aided by grants from the National Institutes of Health and the Dysautonomia Association.

$\dagger$ John and Mary R. Markle Scholar in Medical Science.

1 The following trivial names for steroids are used in this paper: cortisol, $11 \beta, 17 \alpha, 21$-trihydroxy-4-pregnene-3, 20-dione: tetrahydrocortisone, $3 \alpha, 17 \alpha, 21$-trihydroxy-pregnane-11,20-dione; tetrahydrocortisol, $3 \alpha, 11 \beta, 17 \alpha, 21$-tetrahydroxy-pregnane-20-one; allo-tetrahydrocortisol, $3 \alpha, 11 \beta$, $17 \alpha, 21$-tetrahydroxy-allopregnane-20-one. protein $(10,11)$ would be expected to influence the penetration of cortisol into the CSF. In general, it can be stated that the more lipid-soluble a substance is the more rapidly it enters the CSF, and the less firmly bound it is to plasma protein the higher will be the concentration ratio, CSF/ plasma, at equilibrium $(6,7)$. The purpose of this investigation was to compare the entry into CSF of free cortisol and the water-soluble glucuronides that are important products of cortisol metabolism. The data show that these steroids behave like many other substances $(6,7)$ in that cortisol, a lipid-soluble compound, penetrates readily into CSF, whereas the water-soluble, lipid-insoluble metabolites, tetrahydrocortisone and tetrahydrocortisol glucuronides, do not.

\section{METHODS AND MATERIALS}

Thirty-five experiments were carried out in 16 mongrel dogs ranging in weight from 9 to $22 \mathrm{~kg}$. The animals were anesthetized with intravenously administered pentobarbital sodium in a dose of $30 \mathrm{mg}$ per $\mathrm{kg}$ body weight. Sufficient additional sodium pentobarbital was given intravenously during the experiments to maintain a stable respiratory rate. Cisternal punctures were performed with a 20-gauge spinal puncture needle which was left in situ during each experiment. Whenever CSF so obtained was bloody or xanthochromic, the experiment was terminated and the results were discarded.

Clear CSF, in samples of 0.8 to $1.0 \mathrm{ml}$, were removed at intervals and, in some instances when detailed chemical studies of the steroids in CSF were planned, amounts as large as $15 \mathrm{ml}$ were withdrawn by allowing the open needle to drain for periods of 30 to 60 minutes. Specimens of CSF were frozen within 1 hour after withdrawal and kept at $-20^{\circ} \mathrm{C}$ until analyzed for steroid content.

Samples of blood ( 5 to $20 \mathrm{ml}$ ) were withdrawn in heparinized syringes from occluded veins of fore- or hindlegs. Plasma was quickly separated from cells and stored at $-20^{\circ} \mathrm{C}$. In five instances urine specimens were obtained by catheter from female dogs.

The principal experimental procedure was the intravenous injection over a period of 30 seconds of cortisol 
in the form of its water-soluble ester, the 21-hemisuccinate. ${ }^{2}$ The dose was $8 \mathrm{mg}$ of cortisol (calculated as milligrams of the free steroid) per $\mathrm{kg}$ body weight. The amount chosen was large 1) in a deliberate attempt to achieve high, readily measurable concentrations of cortisol, 2) in order to approximate pharmacologic doses, and 3 ) in order to achieve high plasma concentrations of glucuronides of cortisol metabolites so as to afford the best possible opportunity for these glucuronides to penetrate the blood-CSF barrier. Samples of blood were then drawn at 5 minutes, 30 minutes, and at 30 - to 60 -minute intervals thereafter. In 6 animals this procedure was carried out before and after 11 days of treatment with intramuscular corticotropin, 40 IU per day. ${ }^{3}$ When cortisol alcohol or one of its principal metabolites, tetrahydrocortisone, was injected, the steroid was dissolved in small amounts ( 5 to $10 \mathrm{ml}$ ) of 95 per cent ethanol and the solution was dissolved in 50 to $100 \mathrm{ml}$ of isotonic saline for rapid intravenous infusion.

In 4 animals additional experiments were done in order to detect the specific steroids appearing in blood after cortisol infusion. In these studies, cortisol (as the alcohol, not the 21-hemisuccinate) was administered as described, and large volumes of blood were withdrawn after 1 to 3 hours and the plasma separated and stored at $-20^{\circ} \mathrm{C}$.

Determinations of 17-hydroxycorticosteroids (cortisol) in plasma, CSF and urine were made by the SilberPorter technic (12) as modified in this laboratory (13) and by Peterson, Karrer and Guerra (14). In all instances optical densities of the cortisol-phenylhydrazine reaction product were measured at several wave lengths. To insure specificity in the cortisol determination, all samples not showing an absorption maximum at $410 \mathrm{~m} \mu$ (the absorption maximum of cortisol in this reaction) were discarded. Cortisol measured by this technic is termed "free" steroid, in the sense that it is unconjugated-i.e., not in the form of metabolites reduced in the A ring and conjugated at the 3 position with glucuronic acid. To obtain information about the concentration of such glucuronides, more detailed studies were done. From large volumes of plasma, CSF, and urine, obtained after administration of cortisol, "free" cortisol was partially identified after ethyl acetate extraction, by paper chromatography with an authentic cortisol standard in Bush systems (15), by ultraviolet light absorption at 240 $\mathrm{m} \mu$, by reaction with blue tetrazolium, and measured by the Silber-Porter reaction. For detection of the glucuronides of cortisol metabolites, the aqueous phase, after ethyl acetate extraction for free cortisol, was subjected to hydrolysis. In the case of plasma, protein was first precipitated with large volumes of ethanol, the ethanol was evaporated, the aqueous residue was then diluted with distilled water, and the mixture hydrolyzed. For plasma, CSF, and urine, the hydrolytic procedure was the same. $\beta$-glucuronidase (beef liver) was added to the aqueous phase in concentrations of 300 to 500 units

2 Courtesy of the Upjohn Co.

${ }^{3}$ Courtesy of Organon, Inc. per $\mathrm{ml}$. The $\mathrm{pH}$ was kept at 4.5 to 5.0 with 0.1 sodium acetate-acetic acid buffer. The mixture was incubated for 48 to 120 hours at $37^{\circ} \mathrm{C}$. Hydrolysates were then extracted with ethyl acetate, and the steroids released were chromatographically located and characterized, and measured as above. Recovery of cortisol added to plasma, CSF, and urine is quantitative ( 85 to 105 per cent). With the hydrolytic procedure used, there is no inhibition of the action of $\beta$-glucuronidase upon steroid glucuronides by canine CSF (16).

\section{RESULTS}

\section{Resting levels of cortisol in plasma and CSF} of dogs. Thirteen measurements in 11 anesthetized dogs yielded an average value for plasma 17hydroxycorticosteroid concentration of $10 \mu \mathrm{g}$ per $100 \mathrm{ml}$, a value in the same range as that reported for dogs by Eik-Nes and Brizzee (Table I) (17). The range of values was wide -0 to $33 \mu \mathrm{g}$ per 100 $\mathrm{ml}$. In the same 11 dogs, measurements carried out on 1-ml samples of CSF revealed no detectable cortisol. The validity of a virtually zero value for cortisol in CSF was confirmed by attempts to detect cortisol in CSF samples as large as $7 \mathrm{ml}$. a volume in which the method is sensitive enough to measure reliably concentrations of less than 1 $\mu \mathrm{g}$ per $100 \mathrm{ml}$. Chromatographic studies of similar volumes of CSF also failed to reveal the presence of cortisol.

2. Entry of infused cortisol into CSF. Cortisol21-hemisuccinate, $8 \mathrm{mg}$ per $\mathrm{kg}$, was rapidly injected intravenously in 18 experiments upon 14 anesthetized dogs. In 11 experiments, samples of CSF were obtained 5 minutes after cortisol injection, and in 3 instances detectable concentrations of cortisol were found, indicating rapid entry of the steroid into the CSF compartment (Table I). In all but one experiment cortisol appeared in the CSF 30 minutes after injection. Figure 1. in a typical experiment, shows entry of cortisol into the CSF 5 minutes after administration and a rising concentration of cortisol in CSF, reaching a maximum at 90 minutes, while the concentration of plasma cortisol was falling. The figure also indicates the high plasma cortisol concentration at 5 minutes. In the 10 dogs in which plasma cortisol levels were determined at 5 minutes, the range of concentrations was 447 to $1,440 \mu \mathrm{g}$ per $100 \mathrm{ml}$. (The wide range of values can be attributed in part to errors of 30 to 60 seconds in obtaining the 5-minute sample.) These high values constitute 
TABLE I

Concentration of cortisol in plasma and CSF of 11 dogs after rapid intravenous injection of 8 mg of steroid (cortisol 21-hemisuccinate) per kg body weight

\begin{tabular}{|c|c|c|c|c|c|c|c|c|c|c|}
\hline \multirow[b]{2}{*}{ Dog } & \multirow[b]{2}{*}{ Minutes: } & \multicolumn{9}{|c|}{ 17-Hydroxycorticosteroids (cortisol), $\mu \mathrm{g} \%$} \\
\hline & & $\mathbf{0}$ & 5 & 30 & 60 & 90 & 150 & 180 & 210 & 240 \\
\hline WN & $\begin{array}{l}\text { Plasma } \\
\text { CSF }\end{array}$ & $\begin{array}{l}\mathbf{0} \\
\mathbf{0}\end{array}$ & & $\begin{array}{r}535 \\
21\end{array}$ & $\begin{array}{r}275 \\
44\end{array}$ & $\begin{array}{r}171 \\
26\end{array}$ & 158 & & 81 & \\
\hline $\mathrm{TA}$ & $\begin{array}{l}\text { Plasma } \\
\text { CSF }\end{array}$ & 0 & $\begin{array}{r}447 \\
0\end{array}$ & $\begin{array}{r}350 \\
62\end{array}$ & & $\begin{array}{r}168 \\
71\end{array}$ & & $\begin{array}{r}104 \\
45\end{array}$ & & \\
\hline $\mathrm{WH}$ & $\begin{array}{l}\text { Plasma } \\
\text { CSF }\end{array}$ & $\begin{array}{l}\mathbf{0} \\
\mathbf{0}\end{array}$ & $\begin{array}{r}1,350 \\
0\end{array}$ & $\begin{array}{r}353 \\
48\end{array}$ & & $\begin{array}{r}159 \\
42\end{array}$ & & $\begin{array}{l}61 \\
15\end{array}$ & & $\begin{array}{r}42 \\
0\end{array}$ \\
\hline $\mathrm{BR}$ & $\begin{array}{l}\text { Plasma } \\
\text { CSF }\end{array}$ & $\begin{array}{r}17 \\
0\end{array}$ & $\begin{array}{r}1,221 \\
16\end{array}$ & $\begin{array}{r}574 \\
68\end{array}$ & $\begin{array}{r}433 \\
68\end{array}$ & $\begin{array}{r}268 \\
78\end{array}$ & $\begin{array}{r}148 \\
45\end{array}$ & & & \\
\hline $\mathrm{CH}$ & $\begin{array}{l}\text { Plasma } \\
\text { CSF }\end{array}$ & $\begin{array}{l}\mathbf{0} \\
\mathbf{0}\end{array}$ & $\begin{array}{r}816 \\
0\end{array}$ & $\begin{array}{r}534 \\
20\end{array}$ & $\begin{array}{r}299 \\
52\end{array}$ & $\begin{array}{r}210 \\
61\end{array}$ & $\begin{array}{r}150 \\
42\end{array}$ & & $\begin{array}{r}109 \\
22\end{array}$ & \\
\hline TO & $\begin{array}{l}\text { Plasma } \\
\text { CSF }\end{array}$ & $\begin{array}{l}5 \\
0\end{array}$ & $\begin{array}{r}875 \\
0\end{array}$ & $\begin{array}{r}273 \\
71\end{array}$ & $\begin{array}{r}163 \\
90\end{array}$ & $\begin{array}{r}111 \\
61\end{array}$ & $\begin{array}{l}79 \\
38\end{array}$ & & 0 & \\
\hline $\mathrm{SH}$ & $\begin{array}{l}\text { Plasma } \\
\text { CSF }\end{array}$ & $\begin{array}{r}33 \\
0\end{array}$ & $\begin{array}{r}1,030 \\
4\end{array}$ & $\begin{array}{r}505 \\
61\end{array}$ & $\begin{array}{r}296 \\
85\end{array}$ & $\begin{array}{r}230 \\
71\end{array}$ & $\begin{array}{r}141 \\
40\end{array}$ & & 94 & \\
\hline D.t & $\begin{array}{l}\text { 1) Plasma } \\
\text { CSF } \\
\text { 2) Plasma } \\
\text { CSF }\end{array}$ & $\begin{array}{r}21 \\
0 \\
20\end{array}$ & $\begin{array}{r}880 \\
0 \\
1,120 \\
0\end{array}$ & $\begin{array}{r}382 \\
54 \\
365 \\
64\end{array}$ & $\begin{array}{r}244 \\
65 \\
230 \\
47\end{array}$ & $\begin{array}{r}173 \\
73 \\
195 \\
45\end{array}$ & $\begin{array}{l}88 \\
43 \\
73 \\
34\end{array}$ & & & \\
\hline PY & $\begin{array}{l}\text { 1) Plasma } \\
\text { CSF } \\
\text { 2) Plasma } \\
\text { CSF }\end{array}$ & $\begin{array}{r}16 \\
0 \\
9 \\
0\end{array}$ & $\begin{array}{r}810 \\
822 \\
11\end{array}$ & $\begin{array}{r}313 \\
0 \\
376 \\
32\end{array}$ & $\begin{array}{r}178 \\
28 \\
230 \\
31\end{array}$ & $\begin{array}{r}149 \\
23 \\
144 \\
38\end{array}$ & $\begin{array}{l}77 \\
17 \\
78 \\
23\end{array}$ & & & \\
\hline LE & $\begin{array}{l}\text { Plasma } \\
\text { CSF }\end{array}$ & $\begin{array}{l}3 \\
0\end{array}$ & $\begin{array}{r}1,440 \\
0\end{array}$ & $\begin{array}{r}480 \\
76\end{array}$ & $\begin{array}{r}254 \\
94\end{array}$ & $\begin{array}{r}177 \\
72\end{array}$ & $\begin{array}{r}114 \\
54\end{array}$ & & & \\
\hline RA & $\begin{array}{l}\text { Plamsa } \\
\text { CSF }\end{array}$ & $\begin{array}{l}2 \\
\mathbf{0}\end{array}$ & $\begin{array}{r}1,173 \\
0\end{array}$ & $\begin{array}{r}372 \\
41\end{array}$ & $\begin{array}{r}207 \\
87\end{array}$ & $\begin{array}{r}145 \\
94\end{array}$ & $\begin{array}{l}76 \\
54\end{array}$ & & & \\
\hline
\end{tabular}

evidence that the injected material, cortisol hemisuccinate, measured only to a limited extent by the Silber-Porter reaction is rapidly hydrolyzed in vivo to free cortisol which is measured by this colorimetric test. ${ }^{4}$ The graph illustrates a con-

\footnotetext{
${ }^{4}$ Cortisol-21-hemisuccinate, added in vitro to Addisonian plasma with a zero level of cortisol, has a chromogenicity at $410 \mathrm{~m} \mu$ in the Silber-Porter reaction equal to about $15 \%$ of the chromogenicity of free cortisol itself. Therefore, if the steroid ester were incompletely hydrolyzed in vivo, which cannot be excluded in the early (5-minute) samples, the Silber-Porter technic would overestimate plasma cortisol level to a small degree. For example, if as much as $50 \%$ of the ester were not hydrolyzed (and it is unlikely that this much escapes hydrolysis), the concentration of free plasma cortisol would be overestimated by $7.5 \%(0.50 \times 0.15)$. If $20 \%$ remained unhydrolyzed, the overestimation would be $3 \%(0.2 \times 0.15)$. From 30 minutes on it seems unlikely that any of the steroid ester remains unhydrolyzed. There are data indicating that pharmacologic doses of cortisol hemisuccinate behave in
}

stant finding in all studies, namely that in shortterm studies (90 to 120 minutes in duration) with a rapidly falling plasma cortisol concentration, levels of cortisol in CSF never equaled those in plasma. Maximal concentration of cortisol in CSF was reached 60 to 90 minutes after infusion of the steroid.

The rate of disappearance of cortisol was rapid. In the 18 experiments the range of plasma "halftime" was 40 to 93 minutes, with an average of 64 minutes. In six animals the rate of disappearance from plasma of cortisol was calculated in terms of the slope obtained by the method of least squares. This calculation was done in only those

general like free cortisol, both in terms of metabolic fate and absolute values of plasma cortisol attained (18). As will be seen (Section 3 below), the same distribution between plasma and CSF is found with cortisol-21-hemisuccinate as with free cortisol. 


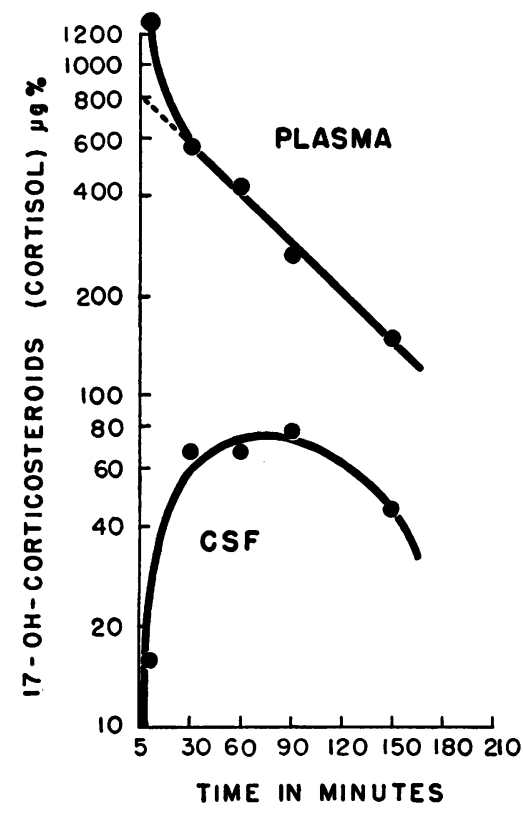

Fig. 1. Plasma and CSF concentrations of cortiSOL in Dog BR (SEe TABle I) AFter Rapid intravenous INJECTION OF CORTISOL 21-hemisuccinate, 8 MG PER KG. Concentration in plasma is high 5 minutes after injection and the steroid is detectable in CSF at that time.

instances in which there was a sufficient number of determinations for adequate mathematical analysis (Table II). The decrease in plasma cortisol level averaged 47.3 per cent per hour, with a range of 40.2 to 53.7. This rate of disappearance

TABLE II

Rate of disappearance Jof cortisol after administration of cortisol 21-hemisuccinate from plasma of 6 dogs before and after corticotropin administration for 11 days*

\begin{tabular}{lcc}
\hline & \multicolumn{2}{c}{$\begin{array}{c}\text { Rate of cortisol } \\
\text { disappearance }\end{array}$} \\
\cline { 2 - 3 } Dog & $\begin{array}{c}\text { Before } \\
\text { corticotropin }\end{array}$ & $\begin{array}{c}\text { After } \\
\text { corticotropin }\end{array}$ \\
\hline & \multicolumn{2}{c}{$\%$ decrease/hr } \\
TA & 40.2 & 40.8 \\
BR & 50.0 & 45.6 \\
CH & 45.5 & 34.3 \\
TO & 42.4 & 48.9 \\
LE & 50.5 & 57.3 \\
RA & 53.7 & 50.2 \\
Mean & 47.3 & 46.7 \\
SD & 5.22 & 7.98 \\
\hline
\end{tabular}

* The data are derived from calculation of the slope of the straight line describing the logarithmic decrement of plasma cortisol concentration. Slope is calculated by the method of least squares. The disappearance rates are essentially the same before and after corticotropin ( $p>$ 0.50 ). is considerably more rapid than that found in normal human subjects (27 per cent per hour) (18) or "half-time" of 138 minutes (19).

3. The steady state distribution of cortisol between plasma and CSF. A constant infusion of cortisol 21-hemisuccinate, $300 \mathrm{mg}$, was given in $1,500 \mathrm{ml} 5$ per cent $\mathrm{D} / \mathrm{W}$ over a 9 -hour period to a $15 \mathrm{~kg}$ dog after a priming dose of $22.5 \mathrm{mg}$. Samples of plasma and CSF were obtained after 4 hours and maintained for the succeeding 5 hours. Cortisol concentration in plasma during this equilibrium state was $200 \mu \mathrm{g}$ per $100 \mathrm{ml}$; in CSF, $40 \mu \mathrm{g}$ per $100 \mathrm{ml}$. The distribution ratio CSF/ plasma of 0.2 is not corrected for protein-binding of the steroid $(10,11)$ nor for the differences in water content of the two compartments.

A second steady state experiment in another animal was done with cortisol alcohol. At equilibrium the concentration ratio, CSF/plasma of cortisol $(53 / 211 \mu \mathrm{g}$ per $100 \mathrm{ml})$ was 0.25 . The similarity of the CSF/plasma ratios in the two studies is interpreted to signify that the steroid hemisuccinate behaves physiologically like the free steroid.

4. Identification and measurement of steroid entering the CSF. In this series of experiments an attempt was made to learn whether or not certain water-soluble metabolites of cortisol, the A-ring reduced, 3-glucuronides, entered the CSF after cortisol injection. These metabolic products are among the chief urinary steroids recovered in urine after administration of cortisol (20). Accordingly, these reduced steroids were sought in blood and urine as well as in CSF (see Methods). Fourteen experiments were carried out in this effort to find tetrahydrocortisone or tetrahydrocortisol in CSF. In five instances measurements for tetrahydrocortisol glucuronide were made in serial small samples $(1 \mathrm{ml})$ of CSF after cortisol hemisuccinate injection, at times when CSF levels of free cortisol were elevated. In no case was tetrahydrocortisol glucuronide found. In nine further studies after cortisol injection, the detailed measurements were made in blood and urine to ascertain that plasma concentrations of tetrahydrocortisol glucuronide were high enough to allow passage into the CSF. After injection of cortisol alcohol, the steroid was recovered from all the fluids investigated; $200 \mathrm{mg}$ of cortisol was given intravenously, and blood was collected during the 
period, 30 to 100 minutes after injection, while CSF was being drained through an indwelling cisternal needle. In a representative experiment the plasma level of free cortisol was $1,040 \mu \mathrm{g}$ per 100 $\mathrm{ml}$, while the level in CSF was 183. Glucuronide content, measured as Silber-Porter reactive material after glucuronidase hydrolysis, was $219 \mu \mathrm{g}$ per $100 \mathrm{ml}$ in plasma-a high value-while none was detectable in CSF.

The apparent failure of steroid glucuronides to enter CSF was further studied. In four dogs steroids were isolated from blood, CSF, and urine by paper chromatography (see Methods). In all instances cortisol was identified in the three fluids after steroid injection (100 to $300 \mathrm{mg}$ of free cortisol in two instances, of cortisol 21-hemisuccinate in the remaining two). Tetrahydrocortisol glucuronide was identified in blood and urine, never in the CSF. [It is of considerable interest from the point of view of steroid metabolism that no tetrahydrocortisone was recovered after cortisol injection. It appears that this represents a species difference between dog and man; in man, cortisol is metabolized to tetrahydrocortisol, allotetrahydrocortisol, and tetrahydrocortisone (21).] Pooled serial blood samples from the four animals showed an average value for free cortisol after chromatography of $180 \mu \mathrm{g}$ per $100 \mathrm{ml}$. The mean value of plasma tetrahydrocortisol after hydrolysis and chromatography was $70 \mu \mathrm{g}$ per 100 $\mathrm{ml}$. The two steroids were also indentified in large quantities in the urine. In the 4-hour urine aliquot it was possible to recover $12.5 \mathrm{mg}$ of conjugated tetrahydrocortisol, $7.7 \mathrm{mg}$ of free cortisol. Chromatographic analysis of many large samples of CSF yielded an average cortisol value for the four dogs of $109 \mu \mathrm{g}$ per $100 \mathrm{ml}$. These studies failed to reveal even trace amounts of tetrahydrocortisol after glucuronidase hydrolysis.

The data indicate that cortisol is metabolized to a reduced steroid which is conjugated with glucuronic acid, but that this metabolite, tetrahydrocortisol glucuronide, does not detectably enter the CSF, although present in plasma in high concentration.

5. Entry into CSF of tetrahydrocortisone, an $A$-ring-reduced, unconjugated metabolite of cortisol. The possibility existed that some property of tetrahydrocortisol other than its existence in plasma as a water-soluble conjugate of glucuronic

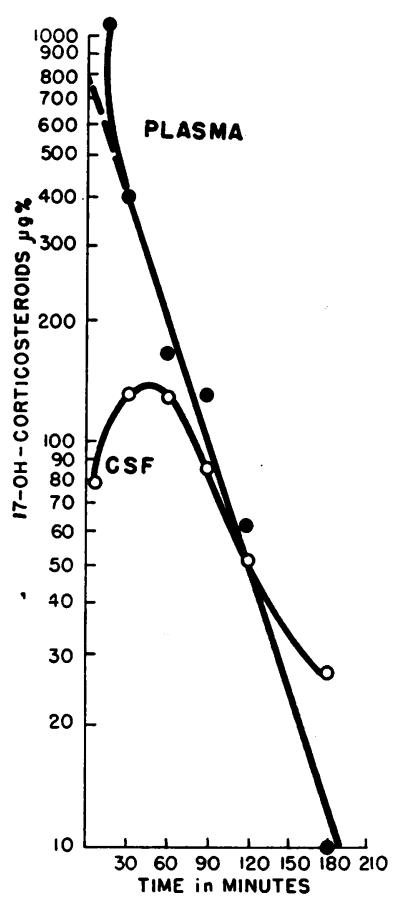

Fig. 2. Plasma and CSF concentrations of tetraHYDROCORTISONE IN DOG BL AFTER RAPID INTRAVENOUS INJECTION OF TETRAHYDROCORTISONE, 8 MG PER KG. Concentration of steroid in CSF at 5 and 30 minutes is higher than concentration attained after comparable doses of cortisol (see text). Rate of tetrahydrocortisone disappearance from plasma is nearly twice as rapid as that of cortisol (rate of decrease of plasma level, $74 \%$ per hour, or plasma "half-time," 35 minutes).

acid was responsible for its exclusion from CSF. A closely related compound, free tetrahydrocortisone, ${ }^{5} 8 \mathrm{mg}$ per $\mathrm{kg}$ body weight, was given intravenously over 30 seconds to two dogs. The free steroid entered the CSF rapidly, as is shown in Figure 2 and Table III. In the experiment illustrated, concentration of 17-hydroxycorticosteroid in CSF at 5 minutes was $66 \mu \mathrm{g}$ per $100 \mathrm{ml}$ (Table III). These concentrations of steroid in CSF were higher than those attained in any of 13 experiments with cortisol at the 5-minute point (Table I). After cortisol injection, concentrations of the steroid in CSF at 5 minutes ranged from 0 to $16 \mu \mathrm{g}$ per $100 \mathrm{ml}$ in the face of concentrations in

5 Provided through the courtesy of Merck and Co. Tetrahydrocortisone was used instead of tetrahydrocortisol because the latter steroid was not readily available in large quantities. Since tetrahydrocortisone and tetrahydrocortisol behave alike physiologically (22), it is reasonable to assume that they are interchangeable for the purpose of this experiment. 
TABLE III

Concentration of tetrahydrocortisone in plasma and CSF of Dogs $B L$ and $D A$ after rapid intravenous injection of 8 mg of steroid per $k g$ body weight*

\begin{tabular}{|c|c|c|c|c|c|c|c|c|c|}
\hline \multirow[b]{2}{*}{ I) og } & \multirow[b]{2}{*}{ Minutes: } & \multicolumn{8}{|c|}{$\begin{array}{l}\text { 17-Hydroxycorticosteroids } \\
\text { (tetrahydrocortisone), } \mu \mathrm{g} \%\end{array}$} \\
\hline & & 5 & 30 & 60 & 90 & 120 & 150 & 180 & 240 \\
\hline $\mathrm{BL}$ & CSF $^{\text {Plasma }}$ & $\begin{array}{r}1,090 \\
82\end{array}$ & $\begin{array}{l}412 \\
133\end{array}$ & 166 & $\begin{array}{r}130 \\
87\end{array}$ & $\begin{array}{l}62 \\
51\end{array}$ & . & $\begin{array}{r}8 \\
27\end{array}$ & $\begin{array}{l}\mathbf{0} \\
\mathbf{0}\end{array}$ \\
\hline D.A & $\begin{array}{l}\text { Plasma } \\
\text { CSF }\end{array}$ & $\begin{array}{r}955 \\
66\end{array}$ & $\begin{array}{r}391 \\
48\end{array}$ & $\begin{array}{r}219 \\
46\end{array}$ & $\begin{array}{r}125 \\
43\end{array}$ & $\begin{array}{l}77 \\
29\end{array}$ & $\begin{array}{l}65 \\
26\end{array}$ & & \\
\hline
\end{tabular}

plasma comparable with those found after tetrahydrocortisone injection. In the two experiments the rate of disappearance of tetrahydrocortisone was rapid, plasma "half-time" being 35 and 39 minutes. Calculated from the slope derived by the method of least squares, decrease in plasma level was 74 per cent per hour, compared with a mean decrease of 47.3 per cent per hour for cortisol (Table II). Free tetrahydrocortisone and tetrahydrocortisone glucuronide were identified in plasma and urine, only free tetrahydrocortisone in the CSF. The more rapid rate of disappearance of tetrahydrocortisone than of cortisol (23), and the virtual absence of conversion of tetrahydrocortisone to tetrahydrocortisol in the dog, are findings in agreement with those made in human subjects (24).

6. The effect of adrenocorticotropin upon the permeability of the blood-CSF barrier to cortisol. This section summarizes the results of determination of cortisol clearance rate and entry into CSF before and after 11-day courses of corticotropin in six dogs. ACTH administration had no effect upon the rate of clearance of cortisol from plasma. Table II shows that the slope of the line describing cortisol disappearance rate is unchanged after 11 days of corticotropin. The rate of cortisol disappearance in the control studies averaged 47.3 per cent per hour; the average after ACTH administration was 46.7 per cent per hour, $\mathrm{p}>0.5$.

Analysis of ratios of $\mathrm{CSF} /$ plasma concentrations of cortisol at $30,60,90$ and 150 minutes showed no significant difference between the control and experimental values. This schedule of corticotropin administration therefore does not appear to alter the permeability of the blood-CSF membranes with regard to cortisol.
Comparison of the disappearance rates and cortisol entry into CSF at different times (i.e., 11 days apart) seems a valid procedure in view of a control study in which three dogs received standard cortisol-21-hemisuccinate infusions before and after periods of 11 days during which no ACTH was given. None of the indices changed significantly during this time.

\section{DISCUSSION}

The data show that free cortisol enters the CSF rapidly in the dog after intravenous injections of large amounts of the steroid. The failure to detect cortisol in CSF of the "resting" dog is in agreement with the data Abelson, Baron and Toakley obtained from human subjects (4). They reported low cortisol concentrations in human CSF ( 0.2 to $0.4 \mu \mathrm{g}$ per $100 \mathrm{ml}$ ) in the resting state, using very large volumes of CSF for chromatographic isolation and quantitation of cortisol (4). Sandberg, Eik-Nes, Nelson and Tyler (3) found no detectable cortisol in small samples of "resting" CSF in man, except for ten instances of central nervous system disease in which the permeability of the blood-CSF barrier is presumably altered (acute poliomyelitis, pneumococcal meningitis, cerebral vascular accidents). In man, Abelson, Baron and Toakley (4) and Cranny and Kelley (5) have demonstrated the rapid entry of cortisol into CSF after administration of cortisol or cortisone, and Cranny and Kelley presented evidence suggesting that the amount of cortisol entering the CSF is increased by the presence of meningeal infection (5). The single observation of Hellman and associates (25) that cortisol-4-C ${ }^{14}$ could not be found in human CSF 8 hours after administration of the steroid can probably be ascribed to the fact that the CSF level after 8 hours would be expected to be exceedingly low.

The data of the present report also show that after injection of cortisol in the dog. only free cortisol, not its reduced glucuronide conjugates, enters the CSF in measurable quantities over periods of 30 to 210 minutes. The rate of entry of steroid, as of other substances $(6,7,9)$, into the CSF is dependent upon several factors. Among these are the permeability characteristics of the complex membranes which constitute the bloodCSF "barrier." These include the membranes of the cerebral capillary endothelium, the pia-glial 
complex, the cerebral astroglia, choroid plexus, and the ependymal and arachnoidal surfaces $(6,7)$. The blood-CSF barrier serves to stabilize the composition of the CSF and the extracellular fluid of the brain, and contributes to the maintenance of a constant internal environment for the central nervous system.

The entry of cortisol into the CSF, and the exclusion from the CSF of water-soluble steroid glucuronides are findings in agreement with those made in the case of other natural and synthetic compounds (6). It appears that a major factor, perhaps the chief factor that determines the difference in penetration into the CSF between free cortisol and tetrahydrocortisone, on the one hand, and tetrahydrocortisol glucuronide and tetrahydrocortisone glucuronide on the other, is the high degree of lipid-solubility of the free (or undissociated) form and the negligible lipid solubility of the polar, dissociable glucuronide. Since no steroid glucuronide entered the CSF when plasma concentrations were far above the physiologic range, it is hardly conceivable that they cross the bloodCSF barrier at the lower concentrations obtaining under physiologic conditions.

The influence of lipid-solubility upon the rate and degree of entry into CSF (steady state CSF/ plasma ratio) of such foreign substances as sulfonamides and barbiturates is marked: the greater the lipid-solubility of the particular substance, the greater is its penetration into the CSF (6). To date, no such orderly arrangement can be made in the case of the free steroids as a group, because only cortisol has been studied extensively.

In addition to lipid-solubility, molecular size might be supposed to influence entry of compounds into $\operatorname{CSF}(6,26)$. However, the relatively small difference in molecular weight between cortisol (mol wet 360) and tetrahydrocortisol glucuronide (mol wt 540) is considered to be of negligible importance in view of the rapid entry of molecules as large as serum albumin into the CSF (27).

The $\mathrm{pK}$ of a compound plays a role in the degree and rate of its entry into CSF : pK influences the plasma-CSF distribution of salts of weak acids and bases (9). The normally lower $\mathrm{pH}$ of CSF as compared with that of plasma does not influence the distribution of non-ionized substances such as free steroid hormones. The $\mathrm{pH}$ gradient would tend to favor the exclusion of weak acids such as the glucuronides of steroids (9). There are no available data concerning the $\mathrm{pK}$ of steroid glucuronides; one would expect it to approximate that of glucuronic acid itself.

The degree to which a substance is bound to protein is also of great importance in determining its distribution (steady state ratio) between plasma and CSF. This is true of calcium, bilirubin and many drugs (6). The observed steady state ratio (CSF/plasma) of cortisol of approximately 0.2 may be considered a consequence of binding of cortisol to plasma protein. There is disagreement in the literature concerning the precise quantity of cortisol that is physiologically bound to protein in man. The estimates range from 72 to 94 per cent bound to protein at $37^{\circ} \mathrm{C}$, the per cent bound being in part dependent upon the plasma concentration of cortisol $(11,22,28-30)$. There is also disagreement about the degree of cortisol binding to plasma protein in the dog. Daughaday found little evidence of corticosteroid-binding-globulin activity in canine plasma, and ascribed most of the 60 to 75 per cent binding observed to albumin (30). Slaunwhite and Sandberg found that only 8 to 40 per cent of added cortisol was bound by dog plasma (11), but Florini and Buyske reported that cortisol binding to plasma in the dog is similar to that in man-i.e., 60 to 90 per cent over a wide range of concentrations (31). The present study provides no data which resolve these differences. However, the observed steady state ratio of 0.2 (CSF/plasma) is compatible with the estimate that 20 per cent of cortisol is unbound, and available for entry from plasma into CSF. 6

A transfer rate constant (9) for cortisol was not derived, because almost all of the data were obtained after a single, rapid intravenous injection of cortisol rather than with maintenance of a constant plasma level. This experimental design was chosen primarily to obtain information regarding the disappearance of cortisol from

\footnotetext{
6 The data are comparable with those obtained by Upton and Bondy who studied cortisol binding to plasma protein in human subjects (32). Over a wide range of high concentrations of cortisol in human plasma, these workers found that about $15 \%$ of the steroid was ultracentrifugable, i.e., that $85 \%$ was tightly bound to plasma protein (presumably to the globulin fraction), and 15\% was bound only loosely (perhaps to albumin) $(10,32)$.
} 
plasma which could not be readily obtained from steady state experiments.

The data show clearly that free tetrahydrocortisone disappears from plasma and enters CSF more rapidly than does free cortisol. This difference may be explained in part by the fact that less tetrahydrocortisone than cortisol is bound to plasma protein (33). At present, data concerning tetrahydrocortisone binding to plasma protein have been reported only in man (33), and it may not be permissible to assume a similar difference in binding of the two steroids in dog plasma. However, no other physical or chemical property appears to account so well for the differences noted, the lipid solubilities and molecular weights of the two steroids being nearly identical.

The high levels of cortisol observed in CSF after injection of large amounts of the steroid are considered to approximate the "diffusible" fraction of the steroid in the plasma. The high concentrations of hormone in the CSF achieved by parenteral administration lead to the conclusion that intrathecal administration of steroids is unnecessary. If one assumes that cortisol is distributed like other lipid-soluble substances, then the concentration of the steroid at equilibrium would be higher in brain than in either CSF or plasma (6). In any disease process that is associated with an increased concentration of protein in the CSF, reflecting a change in the permeability characteristics of the blood-CSF membranes, one would anticipate that concentrations of cortisol in CSF after oral or intravenous administration would be considerably higher than those observed under the relatively normal conditions of the studies here reported.

The data of the present study appear to show that intramuscular administration of ACTH for 11 days does not enhance the penetration of cortisol into the CSF. The same dosage schedule of ACTH has also been shown to bring about no change in the exchange of sodium $\left(\mathrm{Na}^{24}\right)$ between plasma and CSF (34). The absence of an altered rate of cortisol clearance from plasma after ACTH administration is a finding in accord with certain earlier studies, but not in agreement with others. Berliner, Keller and Dougherty (35) demonstrated in mice that pretreatment with corticotropin did not prolong the plasma half-time of injected cortisol. Wallace, Leilop, Carter and
Lyons (36) found no decrease in rate of cortisol disappearance from plasma in human subjects treated with intramuscularly administered ACTH for long periods. In contrast, Kuipers, Ely and Kelley (37) observed a modest prolongation of plasma half-time of infused cortisol after the acute intravenous injection of corticotropin. Dougherty and Berliner (38) reported similar findings in mice, and DeMoor, Hendrikx and Hinnekens reported a delay in disappearance of cortisol from plasma in normal and Addisonian human subjects immediately after ACTH administration (39). Berliner and co-workers have attempted to explain such a prolongation of plasma half-time of cortisol by their reported observations of inhibition by ACTH of hepatic conjugation of metabolites of this steroid with glucuronic acid in rats and mice, an "extra-adrenal effect" of ACTH (35). This hypothesis remains to be proved. In the meantime, the differences in results may be best accounted for by differences in route and chronicity of ACTH administration.

\section{SUMMARY}

1. The resting concentration of cortisol in cerebrospinal fluid (CSF) is less than $1 \mu \mathrm{g}$ per $100 \mathrm{ml}$ in the anesthetized dog.

2. After intravenous injection of cortisol or cortisol-21-hemisuccinate, the steroid enters the CSF rapidly, appearing within 5 to 30 minutes.

3 . In a single experiment prolonged infusion of cortisol-21-hemisuccinate resulted by the fourth hour in the attainment of a steady state ratio, $\mathrm{CSF} /$ plasma, of 0.2 . This can be interpreted as reflecting an 80 per cent binding of cortisol to plasma protein.

4. After cortisol or cortisol-21-hemisuccinate injection, only free (unconjugated) steroid, not the glucuronides of cortisol metabolites, appears in CSF, although a conjugated metabolic product, tetrahydrocortisol glucuronide, is found in high concentration in plasma and urine. These findings are in accord with those concerning most drugs and natural products; i.e., that nonpolar, water-insoluble substances enter CSF from blood more readily than do polar, water-soluble compounds.

5. Another metabolic product of cortisol, tetrahydrocortisone, freely enters the CSF, but tetrahydrocortisone glucuronide does not. The more 
rapid entry into CSF of tetrahydrocortisone than of cortisol may be explained by the lesser degree of binding to plasma protein of the former steroid.

6. In the dog, cortisol appears to be metabolized to tetrahydrocortisol only, not to tetrahydrocortisol, allo-tetrahydrocortisol, and tetrahydrocortisone, as in man. ${ }^{7}$

7. Administration of corticotropin for 11 days to 6 dogs did not enhance the entry of administered cortisol into the CSF, nor did it alter the rate of clearance of cortisol from plasma.

\section{ACKNOWLEDGMENT}

The authors wish to express their thanks to Dr. John W. Fertig for advice regarding statistical analysis; to Dr. Andrew G. Frantz for his help in the adaptation of chromatographic technics; and to Miss Elsie C. Ewen, Miss Pauline A. Dotzler, and Mr. Ado Fleischmann for their technical assistance.

\section{REFERENCES}

1. Bush, I. E., and Sandberg, A. A. Adrenocortical hormones in human plasma. J. biol. Chem. 1953, 205, 783.

2. Romanoff, E. B., Hudson, P., and Pincus, G. Isolation of hydrocortisone and corticosterone from human adrenal vein blood. J. clin. Endocr. 1953, $13,1546$.

3. Sandberg, A. A., Eik-Nes, K., Nelson, D. H., and Tyler, F. H. Levels of 17-hydroxycorticosteroids in body fluids. J. Lab. clin. Med. 1954, 43, 874.

4. Abelson, D., Baron, D. N., and Toakley, J. G. Studies of cerebrospinal fluid following oral administration of cortisone acetate or hydrocortisone. J. Endocr. 1955, 12, 87.

5. Cranny, R. L., and Kelley, V. C. The use of hydrocortisone in the treatment of tuberculous meningitis. A study of steroid concentrations in cerebrospinal fluid. J. Dis. Child. 1958, 96, 165.

6. Davson, H. Intracranial and intraocular fluids in Handbook of Physiology, J. Field, Ed. Washington, Amer. Physiol. Society, 1960, vol. III, p. 1761.

7. Tschirgi, R. D. Chemical environment of the central nervous system in Handbook of Physiology, $\mathrm{J}$. Field, Ed. Washington, Amer. Physiol. Society, 1960, vol. III, p. 1865.

\footnotetext{
' Since this manuscript was submitted, Gold has reported studies of radioactive metabolites of cortisol-4- $\mathrm{C}^{\text {14 }}$ in the dog (40). Although $3 \beta$-hydroxy- $5 \alpha$-pregnane metabolites were found, conversion of cortisol to allo-tetrahydrocortisol occurred to such a small extent that the compound could not be identified: similarly, conversion to tetrahydrocortisone could not be proved in this species (40).
}

8. Woodbury, D. M. Relation between the adrenal cortex and the central nervous system. Pharmacol. Rev. 1958, 10, 275.

9. Rall, D. P., Stabenau, J. R., and Zubrod, C. G. Distribution of drugs between blood and cerebrospinal fluid: General methodology and effect of pH gradients. - J. Pharmacol. (Kbh.) 1959, 125, 185.

10. Daughaday, W. H. Binding of corticosteroids by plasma proteins. I. Dialysis equilibrium and renal clearance studies. J. clin. Invest. 1956, 35, 1428.

11. Slaunwhite, W. R., Jr., and Sandberg, A. A. Transcortin: A corticosteroid-binding protein of plasma. J. clin. Invest. 1959, 38, 384.

12. Silber, R. H., and Porter, C. C. The determination of 17, 21-dihydroxy-20-ketosteroids in urine and plasma. J. biol. Chem. 1954, 210, 923.

13. Christy, N. P., Longson, D., Horwitz, W. A., and Knight, M. M. Inhibitory effect of chlorpromazine upon the adrenal cortical response to insulin hypoglycemia in man. J. clin. Invest. 1957, 36, 543.

14. Peterson, R. E., Karrer, A., and Guerra, S. L. Evaluation of Silber-Porter procedure for determination of plasma hydrocortisone. Analyt. Chem. 1957, 29, 144.

15. Bush, I. E. Methods of paper chromatography of steroids applicable to the study of steroids in mammalian blood and tissues. Biochem. J. 1952, 50, 370.

16. Christy, N. P. Inhibitory effect of canine and human plasma upon enzymatic hydrolysis of steroid glucuronides (abstract). J. clin. Invest. 1959, 38, 995.

17. Eik-Nes, K., and Brizzee, K. R. Adrenocortical activity and metabolism of 17-hydroxycorticosteroids in thyroidectomized dogs. Amer. J. Physiol. 1956, 184, 371.

18. Christy, N. P., Wallace, E. Z., Gordon, W. E. L., and Jailer, J. W. On the rate of hydrocortisone clearance from plasma in pregnant women and in patients with Laennec's cirrhosis. J. clin. Invest. 1959, 38, 299.

19. Scheuer, J., and Bondy, P. K. The effect of intravenous cortisol injections on the plasma cortisol concentration in man. J. clin. Invest. 1957, 36, 67.

20. Lieberman, S., and Teich, S. Recent trends in the biochemistry of the steroid hormones. Pharmacol. Rev. 1953, 5, 285.

21. Fukushima, D. K., Bradlow, H. L., Hellman, L., Zumoff, B., and Gallagher, T. F. Metabolic transformation of hydrocortisone-4- $\mathrm{C}^{14}$ in normal men. J. biol. Chem. 1960, 235, 2246.

22. Peterson, R. E., Nokes, G., Chen, P. S., Jr., and Black, R. L. Estrogens and adrenocortical function in man. J. clin. Endocr. 1960, 20, 495.

23. Peterson, R. E., Wyngaarden, J. B., Guerra, S. L., Brodie, B. B., and Bunim, J. J. The physiologi- 
cal disposition and metabolic fate of hydrocortisone in man. J. clin. Invest. 1955, 34, 1779.

24. Gold, N. I., Smith, L. L., and Moore, F. D. Cortisol metabolism in man: Observations of pathways, pool sizes of metabolites and rates of formation of metabolites. J. clin. Invest. 1959, 38, 2238.

25. Hellman, L., Bradlow, H. L., Adesman, J., Fukushima, D. K., Kulp, J. L., and Gallagher, T. F. The fate of hydrocortisone-4-C $\mathrm{C}^{14}$ in man. J. clin. Invest. 1954, 33, 1106.

26. Fishman, R. A., Ransohoff, J., and Osserman, E. F. Factors influencing the concentration gradient of protein in cerebrospinal fluid. J. clin. Invest. 1958, 37, 1419.

27. Fishman, R. A. Exchange of albumin between plasma and cerebrospinal fluid. Amer. J. Physiol. 1953, 175, 96.

28. Daughaday, W. J., and Mariz, I. K. The binding of steroid hormones by plasma proteins in Biological Activities of Steroids in Relation to Cancer, G. Pincus and E. P. Vollmer, Eds. New York, Academic Press, 1960, p. 61.

29. Mills, I. H., Discussion, p. 261, of Peterson, R. E. The miscible pool and turnover rate of adrenocortical steroids in man. Recent Progr. Hormone Res. 1959, 15, 231.

30. Daughaday, W. H. Binding of corticosteroids by plasma proteins. V. Corticosteroid-binding globulin activity in normal human beings and in certain disease states. A.M.A. Arch. intern. Med. 1958, 101, 286.

31. Florini, J. R., and Buyske, D. A. Plasma protein binding of triamcinolone- $\mathrm{H}^{3}$ and hydrocortisone-4C $^{14}$. J. biol. Chem. 1961, 236, 247.
32. Upton, G. V. and Bondy, P. K. The binding of cortisol by plasma protein. Arch. Biochem. 1958, 78, 197.

33. Daughaday, W. H. Binding of corticosteroids by plasma proteins. III. The binding of corticosteroid and related hormones by human plasma and plasma protein fractions as measured by equilibrium dialysis. J. clin. Invest. 1958, 37, 511.

34. Fishman, R. A. Factors influencing the exchange of sodium between plasma and cerebrospinal fluid. J. clin. Invest. 1959, 38, 1698.

35. Berliner, D. L., Keller, N., and Dougherty, T. F. Tissue retention of cortisol and metabolites induced by ACTH : An extra-adrenal effect. Endocrinology 1961, 68, 621.

36. Wallace, E. Z., Leilop, L. Carter, A. C., and Lyons, H. A. Steroid studies during and after prolonged therapy with $\mathrm{Zn}-\mathrm{ACTH}$. Proc., 42nd Annual Meeting, Endocrine Society, June, 1960.

37. Kuipers, F., Ely, R. S., and Kelley, V. C. Metabolism of steroids: The removal of exogenous 17 hydroxycorticosterone from the peripheral circulation in dogs. Endocrinology 1958, 62, 64.

38. Dougherty, T. F., and Berliner, D. L. The effect of stress and ACTH on the metabolism of hydrocortisone in the liver in Symposium on Liver Function, R. W. Brauer, Ed. Washington, Amer. Inst. of Biol. Sci., 1958, p. 416.

39. DeMoor, P., Hendrikx, A., and Hinnekens, M. Extra-adrenal influence of corticotropin (ACTH) on cortisol metabolism. J. clin. Endocr. 1961, 21, 106.

40. Gold, N. I. Partial characterization of the metabolites of cortisol-4-C $\mathrm{C}^{14}$ in the dog. I. The intact dog. J. biol. Chem. 1961, 236, 1924. 